\title{
The tropical diazotrophic phytoplankter Trichodesmium: biological characteristics of two common species
}

\author{
Edward J. Carpenter ${ }^{1}$, Judith M. O'Neil ${ }^{2}$, Rodger Dawson ${ }^{2}$, Douglas G. Capone ${ }^{2}$, \\ Pirzada J. A. Siddiqui ${ }^{1}$, Till Roenneberg ${ }^{3}$, Birgitta Bergman ${ }^{4}$ \\ ${ }^{1}$ Marine Sciences Research Center, State University of New York, Stony Brook, New York 11794, USA \\ ${ }^{2}$ Chesapeake Biological Laboratory, University of Maryland, Solomons, Maryland 20688, USA \\ ${ }^{3}$ Institut für Medizinische Psychologie, University of Munich, W-8000 Munich 2, Germany \\ ${ }^{4}$ Botaniska Institute, Stockholm University S-106 91, Stockholm, Sweden
}

\begin{abstract}
The 2 tropical cyanobacterial species Trichodesmium thiebautii and T. erythraeum had similar photosynthetic characteristics in the southwestern Sargasso Sea and Caribbean Sea, with mean rates of light saturated photosynthesis (using $\mathrm{O}_{2}$ electrode) of $42\left(\mathrm{SD}=21.3\right.$ ) and $37\left(\mathrm{SD}=18.4\right.$ ) $\mathrm{mg} \mathrm{O}_{2}$ mg chl $a^{-1} \mathrm{~h}^{-1}$ at $1410 \mu \mathrm{E} \mathrm{m}^{-2} \mathrm{~s}^{-1}$, respectively over a $1300 \mathrm{n}$ mile cruise track. Rates of dark respiration were high, and the compensation point for both species was $150 \mu \mathrm{E} \mathrm{m}^{-2} \mathrm{~s}^{-1}$ (ca $55 \mathrm{~m}$, midday). Estimates of carbon doubling times (using photosynthetic quotient) were from 3.0 to $3.8 \mathrm{~d}$ based on expected photosynthetic rates in the water column. The mean rate of nitrogenase activity at $300 \mu \mathrm{E} \mathrm{m}^{-2}$ $\mathrm{s}^{-1}$ by $T$. thiebautii averaged $0.45 \mathrm{nmol}$ ethylene colony ${ }^{-1} \mathrm{~h}^{-1}, 1.6$ times that of $T$. erythraeum $(\mathrm{p}<0.01)$ as observed from samples collected on 3 cruises (64 paired observations). Furthermore, in a comparison of nitrogenase activities, at light intensities between ca 500 and $2500 \mu \mathrm{E} \mathrm{m}^{-2} \mathrm{~s}^{-1}, T$. thiebautii was about twice as active as $T$. erythraeum. The phycoerythrin content of $T$. erythraeum averaged $260 \mathrm{ng}$ colony $^{-1}, 4.4$ times that of $T$. thiebautii, and the mean PE:chl a ratios were 3.2 and 1.2 , respectively. Other pigments: ( $\beta$-carotene, zeaxanthin, myxoxanthophyll, echinenone, and trace pigments) were similar between the 2 species. The organization of subcellular inclusions was distinctly different in these 2 species. The high abundance of $T$. thiebautii relative to $T$. erythraeum in many tropical seas may be due to higher rates of $\mathrm{N}_{2}$ fixation and a previously reported neurotoxin in the former species.
\end{abstract}

\section{INTRODUCTION}

Species in the genus Trichodesmium Ehrenberg are common phytoplankters in tropical waters, often forming extensive blooms, and are important as primary producers and as a source of new nitrogen via $\mathrm{N}_{2}$ fixation (Carpenter \& Romans 1991). The taxonomic validity of the genus Trichodesmium has been noted by Anagnostides \& Komarek (1988), and according to Sournia (1968), the genus Trichodesmium has 4 marine species: $T$. thiebautii Gomont ex Gomont, T. erythraeum Ehrenberg ex Gomont, T. hildebrantii Gomont, and $T$. contorta Wille in Schutt. The 2 species which appear to be most common in tropical seas are $T$. erythraeum and $T$. thiebautii, and the intent of this paper is to determine how these 2 species differ in regard to photosynthetic pigments, nitrogenase activity and the response of photosynthesis to irradiance. Recently, a fragment of the nifH gene was examined in isolates of these 2 putative species (Ben-Porath, Carpenter \& Zehr unpubl.). There were 6 nucleotide differences between them in this highly conserved gene, thus suggesting they are genetically distinct.

These 2 species may be visually distinguished by several criteria. For example, Trichodesmium thiebautii colonies are typically made up of trichomes arranged in parallel in a slightly twisted cylindrical pattern much like a piece of rope (Fig. 1). This species usually appears golden-yellow, although color may vary from gray to red. In contrast, $T$, erythraeum colonies are typically flat, in a 'raft' shape, and are usually darker, sometimes dark red, as compared with $T$. 

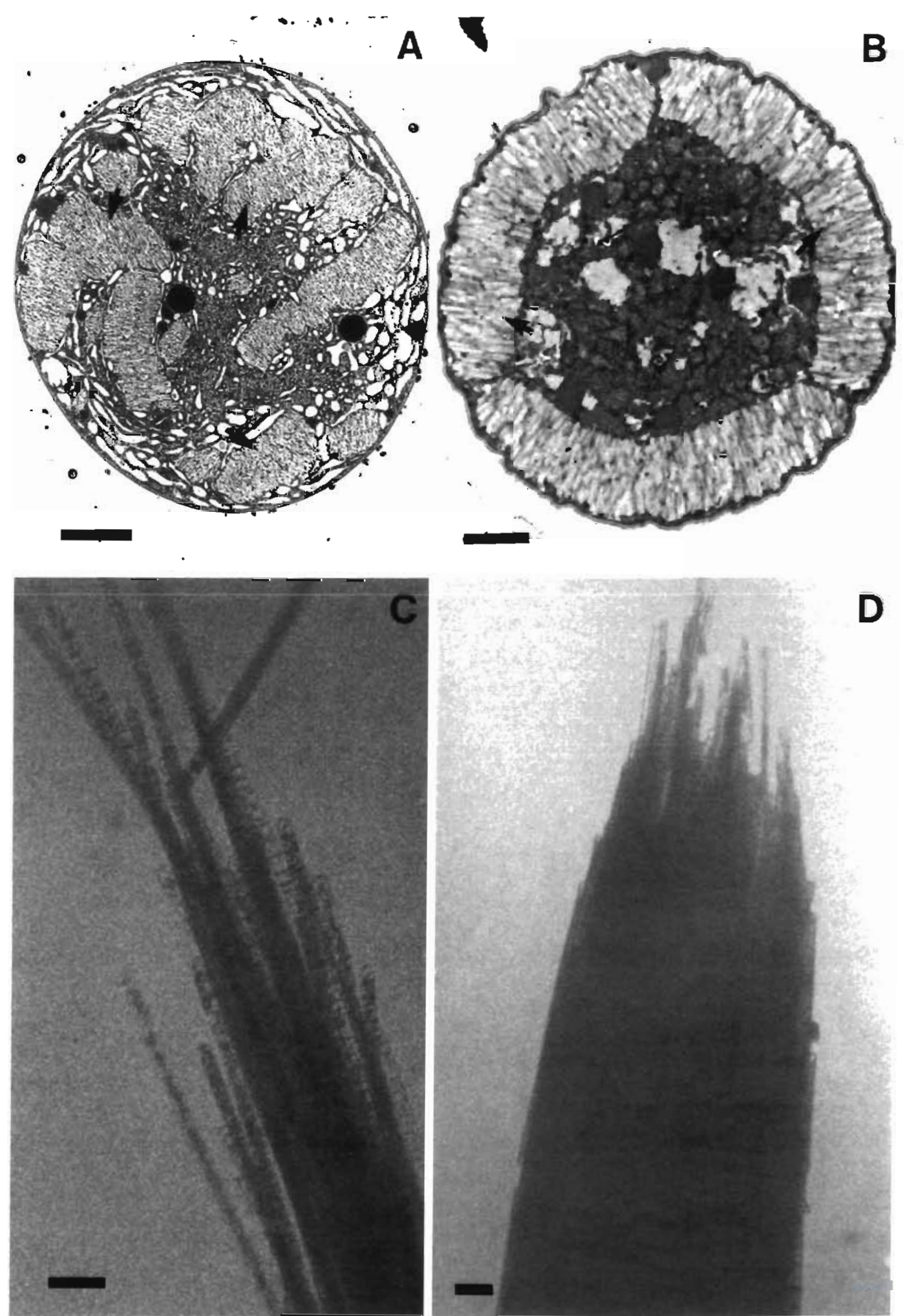

Fig. 1 Trichodesmium thiebautii and $T$ erythraeum. Upper: transmission electron micrographs of cross-sections of cells of: (A) T. thiebautii (bar $=2 \mu \mathrm{m}$ ), (B) $T$. erythraeum (bar $=1 \mu \mathrm{m}$ ) (arrows indicate gas vesicles). Lower: photomicrographs of (C) T. thiebautii and (D) T. erythraeum (bar $=5 \mu \mathrm{m}$ ) showing different arrangements of trichomes in colony 
thiebautii. If these colonies are in a glass beaker, one observes that $T$. erythraeum colonies are more buoyant than $T$. thiebautii and typically rise to the surface then drift to the sides where they can be easily isolated. Further differences, at the microscopic level, are that $T$. erythraeum cells are either as wide as or wider than long (from 7 to $11 \mu \mathrm{m}$ wide, rarely to $21 \mu \mathrm{m}$ ), are slightly constricted at the crosswalls and have a cap or a calyptra at the end of the trichome (Desikachary 1959). Cells of $T$. thiebautii are either as long as or up to twice as long as wide (from 7 to $16 \mu \mathrm{m}$ wide), are not constricted at the crosswalls and have no terminal cap (Desikachary 1959). The collapse pressures of their gas vesicles differ, the mean being 12 bar for $T$. erythraeum and 37 bar for $T$. thiebautii (Walsby 1978). In addition to the collapse pressure differences, Gantt et al. (1984), using transmission electron microscopy, found that the gas vesicles in $T$. thiebautii were smaller and more randomly distributed through the cell than those in $T$. erythraeum. Gas vesicles in T. erythraeum are distributed at the outside of the cell, usually in 4 clusters (Fig. 1). Further differences are that polyphosphate bodies appear to be absent in $T$. thiebautii, but have been observed in $T$. erythraeum. However, poly- $\beta$-hydroxybutyric acid granules, which are used for carbon and energy storage, are present in $T$. thiebautii, but not in T. erythraeum (Siddiqui et al. 1992a, c).

Both species typically coexist in the North Atlantic Ocean, but Trichodesmium thiebautii is often the more abundant (Carpenter \& Price 1977), and in Sagami Bay along the south coast of Japan, T. thiebautii is usually present at a concentration 10 times higher than that of T. erythraeum. (Marumo \& Nagasawa 1976). However, in some locations such as the Indian Ocean, reports indicate that $T$. erythraeum is often more abundant than T. thiebautii (Qasim 1972, Devassy et al. 1978, Bryceson \& Fay 1981).

There appear to be no comparative studies on differences in the physiological ecology of these 2 species. To determine how they differ physiologically, we measured pigment content, photosynthesis, acetylene reduction (nitrogenase) activity and microscopy on samples collected on 4 research cruises to the Caribbean Sea on the RV 'Columbus Iselin', and report the results herein.

\section{MATERIALS AND METHODS}

Samples were collected from 3 to 24 January and 9 to 20 April 1990, 25 January to 16 February 1991, and 17 January to 6 February 1992 in the Bahama Islands and eastern Caribbean Sea. Collections were made by towing a $1 \mathrm{~m}$ diameter net of $222 \mu \mathrm{m}$ mesh at $15 \mathrm{~m}$ depth. Colonies were then isolated with a plastic loop into glass fiber (GF/F) filtered seawater and rinsed again. For transmission electron microscopy, colonies were fixed, dehydrated, and embedded in epoxy resin as described previously (Siddiqui et al. 1992b). Thin sections were observed on a Zeiss $10 \mathrm{TEM}$ at $60 \mathrm{kV}$. For measurement of acetylene reduction, we followed the basic procedure outlined by Capone et al. (1990) for the January 1990 measurements. In these studies, 15 colonies of either Trichodesmium erythraeum or $T$. thiebautii were placed in $5 \mathrm{ml}$ of filtered seawater in a $9 \mathrm{ml}$ glass serum bottle. Samples were incubated indoors in a flowing (taken from $1 \mathrm{~m}$ depth) seawater bath with exposure to light $\left(300 \mu \mathrm{E} \mathrm{m}^{-2} \mathrm{~s}^{-1}\right)$ from a Sylvania or a Colorspec $500 \mathrm{~W}$ incandescent lamp. For a comparison of nitrogenase activity at ambient light, colonies were collected on 19 April 1990, prepared in serum bottles as described above, and incubated in a flowing seawater incubator in full sunlight (ca $2500 \mu \mathrm{E}$ $\mathrm{m}^{-2} \mathrm{~s}^{-1}$ ). Ethylene was measured on $100 \mu \mathrm{l}$ samples of the gas phase which were injected into a Shimadzu Mini II gas chromatograph.

Photosynthesis was determined by measuring oxygen production or consumption with a Hansatech CB1-D electrode control box, and DW1 electrode unit and reaction vessel. Typically, 5 colonies were placed in $1 \mathrm{ml}$ of glass fiber (GF/F) filtered seawater in the reaction vessel, and were cradled above the tefloncovered stir bar on a piece of $64 \mu \mathrm{m}$ mesh netting which was held in place with a ring of polyethylene plastic. The netting ring allowed the colonies to remain intact, prevented contact with the stir bar, yet allowed complete circulation of water in the reaction chamber Temperature around the reaction vessel in the plexiglass water jacket was controlled by water from a circulating water bath (Forma 2095). This was set at ambient water temperature $\left(26.5\right.$ to $\left.28.0^{\circ} \mathrm{C}\right)$.

For the photosynthesis $(P)$ vs irradiance $(I)$ curves, the light source was a Vivitar $3000 \mathrm{AF} 35 \mathrm{~mm}$ slide projector with an Osram HLX Xenophot bulb. Light intensities, measured with a Biospherical Inst. Co. QSP-170 Scalar Irradiance meter, were: dark, 10, 20, 50, 105, $315,630,1410$, and $1950 \mu \mathrm{E} \mathrm{m}^{-2} \mathrm{~s}^{-1}$ and were used in that order (ascending from darkness to highest intensity). Neutral density slides were made with layers of shading film (Cello-Tek Mfg. Co.) set in $35 \mathrm{~mm}$ slide holders. Change in oxygen concentration was measured at each light intensity for from 2 to $4 \mathrm{~min}$. Moles oxygen evolved was converted to moles carbon fixed using a photosynthetic quotient (PQ) of 1.25. After a $P$ vs I curve was run, the chlorophyll a content of the colonies was determined by filtering the entire sample onto a $25 \mathrm{~mm}$ diameter GF/C filter, then placing the filter in $6 \mathrm{ml}$ of $100 \%$ methanol and keeping it in a freezer overnight. The chlorophyll in the extracted sample was then determined, as recommended by 
Holm-Hansen \& Reimann (1978), by fluorescence with a Turner 111 fluorometer. To calculate $P$ vs $I$ curves and the parameters $P_{\max }, \alpha$, and $I_{k}$, oxygen production data were fitted to curves using the formula given by Smith (1936) as follows:

$$
P=P_{\max } \frac{I / I_{k}}{\left[1+\left(I / I_{k}\right)^{2}\right]^{1 / 2}}+R
$$

where $I=$ irradiance $I_{k}=$ light intensity at the junction of the initial slope and $P_{\max }$ and $R=$ rate of dark respiration. The respiration term $(R)$ was added to Smith's equation to yield net photosynthesis.

Pigment content of the 2 species was determined using a high performance liquid chromatography (HPLC) system for the chlorophyll and carotenoid components in Jamuary and February 1991. From 5 to 20 colonies of Trichodesmium thiebautii or $T$. erythraeum were picked fresh from tows, and extracted immediately by sonication with $100 \%$ acetone followed by overnight extraction in the freezer. After centrifugation, the extract was injected into a reverse-phase HPLC, and pigments were separated at a flow rate of $1.1 \mathrm{mi} \mathrm{min} \mathrm{mith}^{-1}$ with a gradient of $90 \%$ acetonitrile/water which was increased to $100 \%$ ethyl acetate over 35 min. The equipment used consisted of a Shimadzu pump with an ELAB low pressure mixing controller programmed by an IBM AT computer, with detection at $436 \mathrm{~nm}$ (Waters 440 detector). A fixed loop (250 $\mu \mathrm{l}$ ) electrically actuated Valco injector delivered sample extracts to the analytical column (Alltech Adsorbosphere $\mathrm{C}-18,25 \mathrm{~cm} \times 4.6 \mathrm{~mm}, 5 \mu \mathrm{m}$ ). The instrument was calibrated with authentic standards previously measured in the home laboratory and stored frozen on board ship. These included chlorophyll a, zeaxanthin, and $\beta$-carotene. Myxoxanthophyll concentrations

Table 1. Trichodesmium erythraeum and T. thiebautii. Chlorophyll a content (ng colon $y^{-1}$ ), phycoerythrin (PE) (ng colony ${ }^{-1}$ ) and trichomes per colony collected in the northeastern Caribbean Sea from $15 \mathrm{~m}$ depth on 6 and 14 January 1990. Data are from several colonies for each measurement. -: not measured

\begin{tabular}{|ccccccc|}
\hline \multirow{2}{*}{ Date } & \multicolumn{3}{c}{ T. erythraeum } & \multicolumn{3}{c|}{ T. thiebautii } \\
& Chl a & PE & Trichomes & Chl a & PE & Trichomes \\
\hline \multirow{2}{*}{ 6 Jan } & 68 & 269 & 406 & 48 & 58 & 465 \\
& 119 & 320 & 467 & 51 & 48 & 505 \\
& 168 & 172 & 490 & 51 & 98 & 441 \\
\multirow{5}{*}{ 14 Jan } & 33 & 239 & 640 & 17 & 33 & 287 \\
& 17 & 294 & 320 & 89 & 70 & 498 \\
& 34 & - & - & 33 & - & - \\
& 82 & - & - & 34 & - & - \\
Mean & 32 & - & - & 58 & - & - \\
SD & 69 & 259 & 465 & 48 & 61 & 439 \\
& 49 & 51 & 106 & 20 & 22 & 79 \\
\hline
\end{tabular}

were quantified using an extinction coefficient of $2160 \mathrm{E}_{\mathrm{cm}}^{\mathrm{i} \%}$ in the absence of a pure standard. In April 1990, chlorophyll a was also measured using a Turner 111 fluorometer as described previously (McCarthy \& Carpenter 1979). The phycoerythrin (PE) content was measured using a Turner Designs fluorometer and the glycerol-uncoupling procedure of Wyman (1992). The fluorometer was calibrated using a water extract of natural Trichodesmium and the extinction coefficients of Moreth \& Yentsch (1970).

\section{RESULTS}

Pigments. The phycoerythrin content of Trichodesmium erythraeum averaged approximately 4.4 times that of T. thiebautii. On 6 and 14 January 1990, mean PE content of $T$. erythraeum was 260 (SD = 51) ng colony ${ }^{-1}$, and the mean for $T$. thiebautii was only $61(\mathrm{SD}=49) \mathrm{ng} \mathrm{PE}$ colony $^{-1}$ (Table 1$)$. The mean chlorophyll a contents of $T$. erythraeum and $T$. thiebautii were similar, $69.1(\mathrm{SD}=49)$ and 47.6 (SD $=$ 20) ng colony ${ }^{-1}$, respectively, but the variance was high. We observed mean PE:chl a ratios of 3.7 for $T$. erythraeum and 1.3 for $T$. thiebautii. In surface water samples collected in 1973 and 1974 south of Japan, the PE content (weight) of $T$. erythraeum averaged 4.4 and 5.2 times that of the chl $a$ in $T$. thiebautii (Aruga et al. 1975). In our measurements, the numbers of trichomes per colony were virtually identical in the 2 species (Table 1), so differences in PE content were not simply due to the presence of more trichomes in a colony.

The dominant pigments, other than phycoerythrin, were chl $a, \beta$-carotene, zeaxanthin and myxoxanthophyll (Table 2). Echinenone was also present in varying proportions. This pattern of pigments agrees with previous reports (Hogetsu \& Watanabe 1975) with the exception that these workers did not report presence of zeaxanthin. A typical chromatogram (Fig. 2) showed trace quantities of cis isomers of zeaxanthin, chl a allomer and epimer, cis-echinenone and an unknown pigment. The unknown component (Fig. 2) had a very similar retention time to that of an acyclic carotene. In general, the samples from the February 1991 cruise showed little signs of appreciable chlorophyll degradation and no phaeophorbides or phaeophytin were detected.

Photosynthesis. Measurements indicated that Trichodesmium eryth- 
Table 2. Trichodesmium erythraeum and T. thiebautii. Pigment content. Samples were collected between 5 and $20 \mathrm{~m}$ depth, water temperature of $26^{\circ} \mathrm{C}$, from 6 to 9 February 1991 in the northeastern Caribbean Sea. Data are ng colony ${ }^{-1}$ for duplicate samples. nd: not detectable

\begin{tabular}{lcc|}
\hline Pigments & T. erythraeum & T. thiebautii \\
\hline \multirow{3}{*}{ Chl a } & 37.2 & 26.7 \\
B-carotene & 16.6 & 48.8 \\
& 0.9 & 0.6 \\
Zeaxanthin & nd & 6.8 \\
\multirow{3}{*}{ Myxoxanthophyll } & 1.8 & 2.9 \\
& 2.9 & 4.8 \\
& nd & 0.9 \\
& 0.3 & 0.4 \\
\hline
\end{tabular}

raeum and $T$, thiebautii were very similar in their photosynthetic characteristics. Eight $P$ vs $I$ curves were collected for $T$. erythraeum, and 22 for $T$. thiebautii in the daytime (between 09:30 and 18:30 h) in a $15 \mathrm{~d}$ period in February 1992 (Fig. 3) over a cruise track which spanned $1300 \mathrm{n}$ miles. Fewer data points were collected for $T$. erythraeum because this species was not as abundant as $T$. thiebautii. Although mean photosynthetic rates for $T$. thiebautii were consistently higher than those from $T$. erythraeum, standard errors for the rate measured at each irradiance overlapped, and there was no statistical difference between the 2 curves (Fig. 3). At $1410 \mu \mathrm{E} \mathrm{m}^{-2} \mathrm{~s}^{-1}$, mean rate of $\mathrm{O}_{2}$ production for $T$. thiebautii was $45 \mathrm{mg} \mathrm{O}_{2} \mathrm{mg}$ chl $\mathrm{a}^{-1}$ $\mathrm{h}^{-1}$, and for $T$. erythraeum the rate averaged 39. At the high light value of $1950 \mu \mathrm{E} \mathrm{m}^{-2} \mathrm{~s}^{-1}$, a small (ca $15 \%$ ) amount of photoinhibition may have been evident for $T$. erythraeum; however, $\mathrm{O}_{2}$ production of colonies was only measured for 2 min at each light intensity, and photoinhibition may be more severe when held longer. Mean rates of $\mathrm{C}$ fixation (calculated using a $\mathrm{PQ}$ of 1.25 ) at $1410 \mu \mathrm{E} \mathrm{m}^{-2} \mathrm{~s}^{-1}$ were 13.6

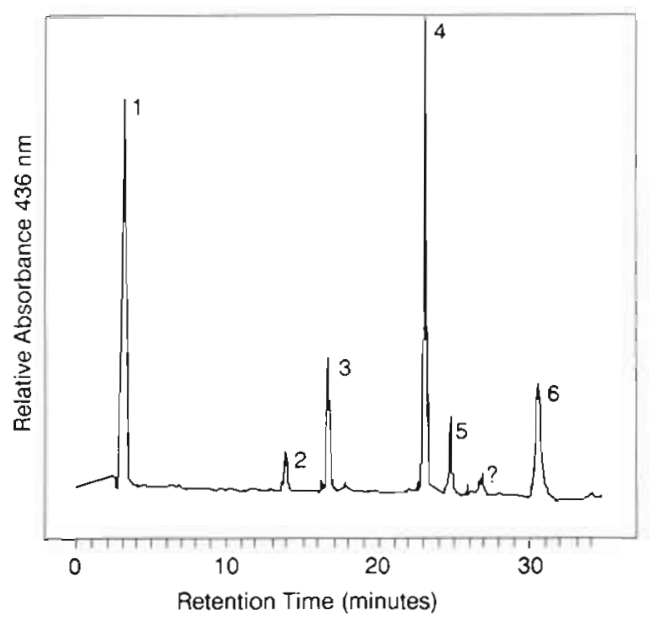

Fig. 2. Trichodesmium thiebautii. Reversed phase chromatogram of an acetone extract of a single tuft from $5 \mathrm{~m}$ depth, February 1991. Peak identities: 1, solvent front; 2, myxoxanthophyll; 3 , zeaxanthin; 4, chlorophyll $a_{i} 5$, echineone; $6, \beta$-carotene

and $11.7 \mathrm{mg} \mathrm{C} \mathrm{mg} \mathrm{chl} \mathrm{a}^{-1} \mathrm{~h}^{-1}$ for $T$. thiebautii and $T$. erythraeum, respectively. The mean light compensation point $(P=R)$ for each was the same, $150 \mu \mathrm{E} \mathrm{m}^{-2}$ $\mathrm{s}^{-1}$. The calculated average $P_{\max }$ for $T$. thiebautii was $42(\mathrm{SD}=21.3) \mathrm{mg} \mathrm{O} \mathrm{mg} \mathrm{chl}^{-1} \mathrm{~h}^{-1}$, and for $T$. erythraeum it was $37(\mathrm{SD}=18.4)$ (Table 3$)$. The mean respiration rate of $T$. erythraeum averaged $67 \%$ higher, $-24.9 \mathrm{mg} \mathrm{O} \mathrm{O}_{2} \mathrm{chl} a^{-1} \mathrm{~h}^{-1}$, than the mean of -14.9 observed for $T$. thiebautii (Table 3). Furthermore, $T$. thiebautii saturated at a higher light intensity than $T$. erythraeum, and the $I_{k}$ values were 687 and $324 \mu \mathrm{E} \mathrm{m}^{-2} \mathrm{~s}^{-1}$, respectively. Mean dark respiration rates in both species were positively correlated with $P_{\max }$ (Fig. 4). A linear regression indicated an $R$ value of 0.63 . Slopes for the 2 species were virtually identical, so data were pooled for one regression ( $Y=6.38+$ $0.24)$. An analysis of respiration and $P_{\max }$ during day-
Fig. 3. Trichodesmium thiebautii and $T$. erythraeum. Photosynthesis $(P)$ vs irradiance (I) curves obtained from $\mathrm{O}_{2}$ electrode and converted to carbon using a $P Q$ of 1.25 , in January and February 1992 in Bahamas and northeastern Caribbean Sea. The $T$. thiebautii curve shows means and SEs (bars) of 24 profiles taken between 08:45 and 17:00 h. The $T$. erythraeum curve is the mean of 8 profiles

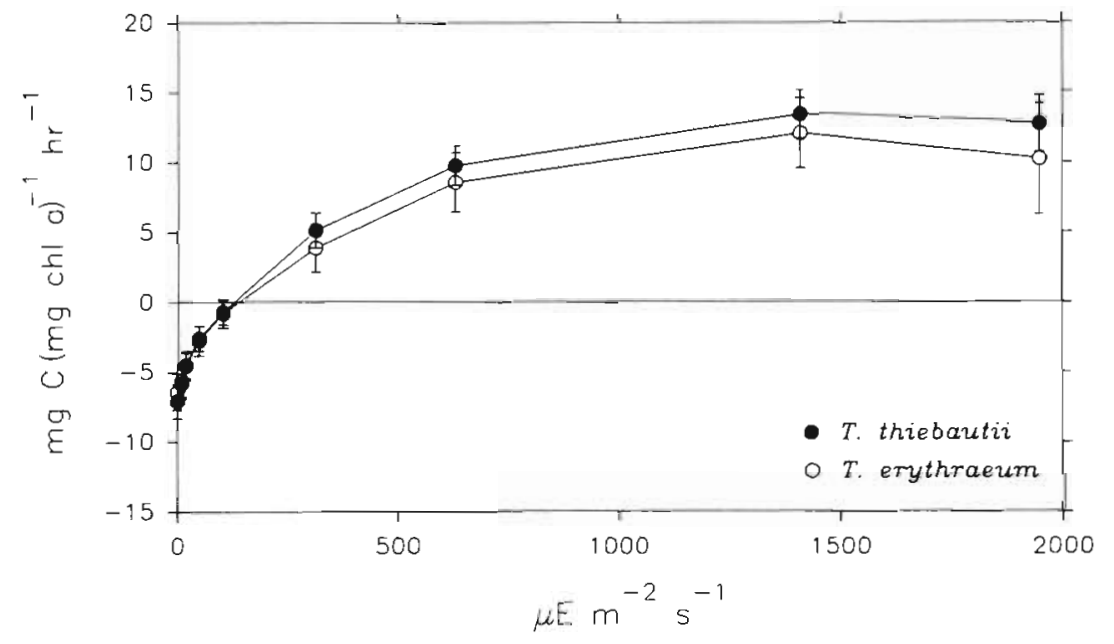


Table 3. Trichodesmium erythraeum and T. thiebautii. Means and SDs of photosynthetic parameters. $T$. erythraeum: $\mathrm{n}=8$; T. thiebautii: $\mathrm{n}=21$

\begin{tabular}{|c|c|c|c|c|}
\hline & \multicolumn{2}{|c|}{ T. erythraeum } & \multicolumn{2}{|c|}{ T. thiebautii } \\
\hline & Mean & $\mathrm{SD}$ & Mean & SD \\
\hline$P_{\max }{ }^{a}$ & 36.9 & 18.4 & 41.9 & 21.3 \\
\hline $\operatorname{Resp}^{a}$ & -24.9 & 5.16 & -14.9 & 6.10 \\
\hline$\alpha$ & 0.108 & 0.068 & 0.067 & 0.023 \\
\hline$I_{k}^{b}$ & 324.2 & 215.5 & 686.5 & 754.5 \\
\hline \multicolumn{5}{|c|}{${ }^{\mathrm{a}} \mathrm{mg} \mathrm{O}_{2} \mathrm{mg} \mathrm{chl} a^{-1} \mathrm{~h}^{-1} ;{ }^{b} \mu E \mathrm{~m}^{-2} \mathrm{~s}^{-1}$} \\
\hline
\end{tabular}

light indicated no relationship between time of sampling and either of these parameters (data not shown).

Nitrogenase activity. For 64 paired comparisons, collected on 3 cruises, of acetylene reduction at $300 \mu \mathrm{E}$ $\mathrm{m}^{-2} \mathrm{~s}^{-1}$, Trichodesmium thiebautii averaged 0.45 and $T$. erythraeum averaged $0.28 \mathrm{nmol}$ ethylene produced colony ${ }^{-1} \mathrm{~h}^{-1}$ (Fig. 5). A paired $t$-test of the means gave significant differences $(p<0.01)$. A comparison of the species on 19 April 1990 indicated that $T$. thiebautil nitrogenase activity was about twice as active as $T$. erythraeum at saturating light intensities (Fig. 6). T. thiebautii may have had some inhibition in nitrogenase activity at full surface light intensity, whereas $T$. erythraeum showed progressive increases up to full surface light intensity.

Particulate $\mathbf{C}$ and $\mathbf{N}$ content. Carbon and nitrogen contents of colonies were virtually identical on the one date they were compared, 7 February 1991. Trichodesmium thiebautii had $11.9 \mu \mathrm{g} \mathrm{C}$ and $2.32 \mu \mathrm{g} \mathrm{N}$, while $T$. erythraeum averaged $11.2 \mu \mathrm{g} \mathrm{C}$ and $2.18 \mu \mathrm{g} \mathrm{N}$ (Table 4). The $C: N$ ratios were 5.13 for $T$. thiebautii and 5.15 for $T$. erythraeum.

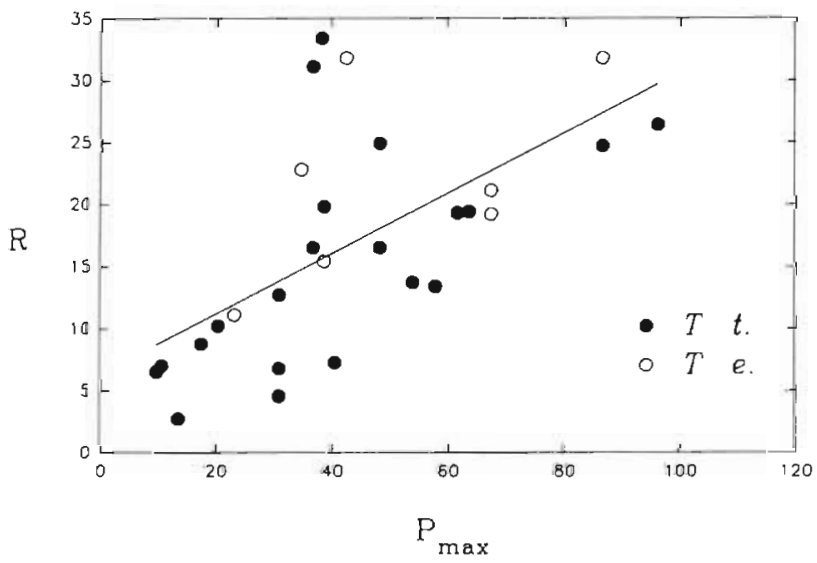

Fig. 4. Trichodesmium thiebautii (o) and $T$. erythraeum ( $\bullet$ ).

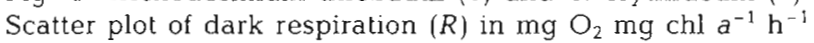
and $P_{\max }$ (same units). $P_{\max }$ was estimated using model of Smith (1936)

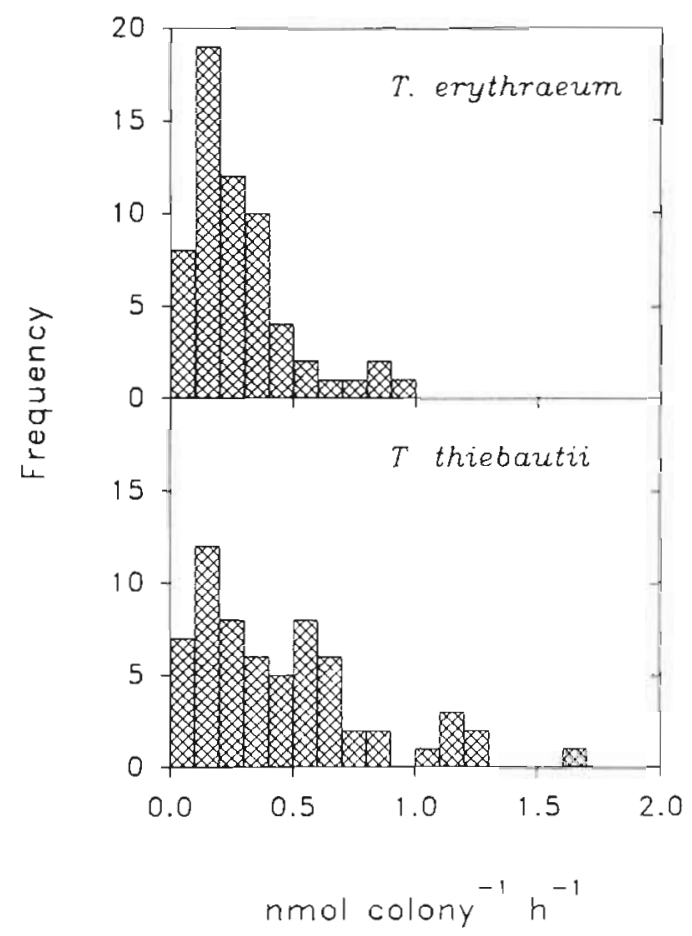

Fig. 5. Trichodesmium thiebautii and T. erythraeum. Histograms of acetylene reduction in nmol ethylene produced colony ${ }^{-1} \mathrm{~h}^{-1}$

\section{DISCUSSION}

There were distinct differences between the 2 species examined. Trichodesmium thiebautii had greater nitrogenase activity at irradiance values found in tropical near-surface waters, and it also had the advantage of possessing a neurotoxin which inhibits grazing by some copepods (Hawser \& Codd 1992). However, T. erythraeum is more buoyant, and has higher concentrations of phycoerythrin. There are other ultrastructural differences, but both are similar as regards photosynthetic rates and photosynthetic pigments other than phycoerythrin.

Overall, both species are clearly adapted to and in need of high light intensities relative to most other marine phytoplankters. The mean $I_{k}$ values, water column irradiances above which light-saturated photosynthesis occurs, were 324 and $686 \mu \mathrm{E} \mathrm{m}^{-2} \mathrm{~s}^{-1}$ for Trichodesmium erythraeum and $T$. thiebauti, respectively (Table 3). These irradiances were similar to that reported by Li et al. (1980) who calculated an $I_{k}$ of $358 \mu \mathrm{E} \mathrm{m} \mathrm{m}^{-2} \mathrm{~s}^{-1}$ for $T$. thiebautii. Using the observed extinction coefficients (Subramaniam \& Carpenter unpubl.) collected with a Biospherical Inst. Co. spectroradiometer on the January 1991 cruise, the typical depths at which these values would be found during midday are at approximately 23 and $35 \mathrm{~m}$. Thus for 


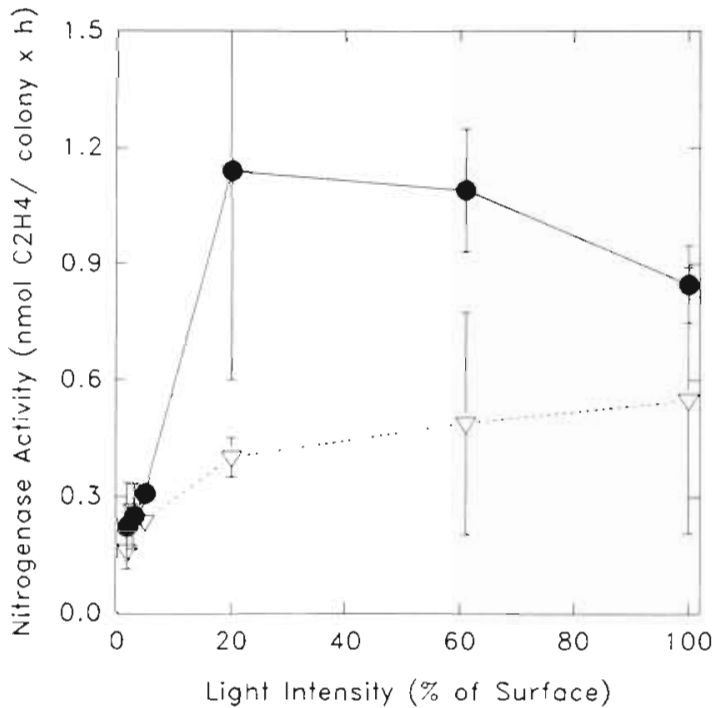

Fig. 6. Trichodesmium thiebautii $(\nabla)$ and $T$. erythraeum (o) Nitrogenase activity at different light intensities. Bars show SD

these species, light-saturated photosynthesis occurs within the region where their population maxima (15 m, Caribbean Sea and southwestern Sargasso Sea; Carpenter \& Price 1977) typically are found.

Walsby (1978) has noted the more rapid floating velocity in Trichodesmium erythraeum as compared with $T$. thiebautii. He speculated that this buoyancy may prevent it from being mixed as deeply as $T$. thiebautii, since $T$. erythraeum has weaker gas vesicles. Those in $T$. erythraeum would collapse at $120 \mathrm{~m}$, while $T$. thiebautii could sink to $370 \mathrm{~m}$ before rupture. This being so, we might thus expect that $T$. erythraeum should therefore be restricted to depths closer to the surface than $T$. thiebautii.

Both species have high rates of respiration, as evidenced here, and previously by Kana (1992). The mean compensation light intensity of $150 \mu \mathrm{E} \mathrm{m}^{-2} \mathrm{~s}^{-1}$ (Fig. 2) is the $6 \%$ light level $\left(I_{0}=2500 \mu \mathrm{E} \mathrm{m}^{-2} \mathrm{~s}^{-1}\right)$ and this would occur at about $55 \mathrm{~m}$ depth (Subramaniam \& Carpenter unpubl.). Carpenter \& Price (1977) had

Table 4. Trichodesmium erythraeum and T. thiebautii. Particulate $\mathrm{C}$ and $\mathrm{N}$ content colony $\mathrm{y}^{-1}$ on 7 February 1991 in the northeastern Caribbean Sea. From 12 to 25 colonies were used for each measurement

\begin{tabular}{|lccc|}
\hline Species & $\mu \mathrm{g} \mathrm{C}$ & $\mu \mathrm{N}$ & $\mathrm{C}: \mathrm{N}$ \\
\hline T. thiebautii & 12.1 & 2.29 & 5.26 \\
& 11.7 & 2.34 & 5.00 \\
T. erythraeum & 11.3 & 2.20 & 5.14 \\
& 11.1 & 2.15 & 5.16 \\
\hline
\end{tabular}

observed earlier that virtually the whole Trichodesmium population in the Caribbean Sea occurs within the upper $50 \mathrm{~m}$, well above the compensation light intensity. Kana (1992), working in the same region, measured an even higher light compensation point of $280 \mu \mathrm{E} \mathrm{m}^{-2} \mathrm{~s}^{-1}$ for Trichodesmium.

Two striking characteristics of the data are the high variation in respiration and $P_{\max }$ and their positive correlation (Fig. 4). Our data indicate about a 10 - and a 4 -fold range in dark respiration values for Trichodesmium thiebautii and $T$. erythraeum, respectively, with a positive correlation with $P_{\max }$ for both species (Fig. 4). The causes of this high variation in respiration and $P_{\max }$ are unknown. Previous research on nitrogenase activity indicates very high (100-fold) variation in activity among colonies collected and assayed simultaneously (Carpenter unpubl.). Colonies at any one depth differ in regard to buoyancy characteristics and presumably to past light history, and this may result in high variation in photosynthetic characteristics. Colony-associated bacteria, protozoa and other heterotrophs certainly contribute to oxygen consumption, but not to evolution, so they could not possibly be a cause of the observed correlation (Fig. 4). Secondly, the cyanobacteria were collected in daytime and were actively photosynthesizing in the water column when collected at $15 \mathrm{~m}$, thus the dark respiration rate must partially reflect their metabolic activity prior to collection. Those with high rates of photosynthesis likely had a high ATP requirement when placed in the dark, and oxidative phosphorylation, using carbohydrate reserves, must also have been high. The fact that $\mathrm{N}_{2}$ fixation in this species is closely coupled to photosythesis may play a role in the observed correlation between respiration and $P_{\max }$. Recently a positive correlation between cytochrome oxidase activity and nitrogenase has been observed in Trichodesmium (Bergman, Siddiqui, Carpenter \& Peschek unpubl.), thus suggesting a linkage of these 2 processes.

Maximal rates of photosynthesis appear to be slightly greater for Trichodesmium thiebautii than for $T$. erythraeum, and respiration rates were higher in the latter species. If $T$. erythraeum is slightly less efficient at photosynthesis, then perhaps its more buoyant nature and exposure to higher light intensities would compensate for its lower photosynthetic efficiency. A further point is that every one of the rather limited number of colonies of $T$. erythraeum collected by Walsby (1978) was positively buoyant, whereas a significant percentage of $T$. thiebautii observed by him were not. In fact, Villareal \& Carpenter (1990) noted diel changes in buoyancy in $T$. thiebautii, but not enough $T$. erythraeum were collected to make conclusions regarding changes in this species. We observed the highest mean rates of photosynthesis at $1410 \mu \mathrm{E}$ 
$\mathrm{m}^{-2} \mathrm{~s}^{-1}$, and it averaged $13.6(\mathrm{SD}=6.17)$ and $11.6(\mathrm{SD}=$ 5.52) $\mathrm{mg} \mathrm{C} \mathrm{mg} \mathrm{chl} a^{-1} \mathrm{~h}^{-1}$ for $T$. thiebautii and $T$. erythraeum, respectively. This is considerably higher than the rates measured by Hogetsu \& Watanabe (1975) southeast of Japan. They observed $P_{\max }$ values from 1.09 to 3.44 (av. $=1.72$ ) $\mathrm{mg} \mathrm{C} \mathrm{mg} \mathrm{chl} a^{-1} \mathrm{~h}^{-1}$ at 22 to $23^{\circ} \mathrm{C}$, and lower values were seen at $21^{\circ} \mathrm{C}$ in January. Field measurements of $P_{\max }$ made on samples collected by Lewis et al. (1988) during a bloom in the Sargasso Sea at $28^{\circ} \mathrm{C}$ indicated a maximal rate of photosynthesis of $3.78 \mathrm{mg} \mathrm{C} \mathrm{mg} \mathrm{chl} \mathrm{a}^{-1} \mathrm{~h}^{-1}$ for Trichodesmium. Strong photoinhibition was observed by Lewis et al. (1988) at irradiances above about $1000 \mu \mathrm{E} \mathrm{m}^{-1} \mathrm{~s}^{-1}$. It may well be that photoprotectant pigments vary with the physiological state of the population, and this may explain why photoinhibition is seen in some natural samples, but not in others. Furthermore, Lewis et al. (1988) used longer ${ }^{14} \mathrm{C}$ incubations to measure photosynthesis, and exposure to high light for long periods may have led to photoinhibition.

The calculated rates of carbon fixation in our study were high and indicate that the population in the southwestern North Atiantic was growing rapidly. Cellular carbon doubling times can be calculated for the populations in near-surface waters. With midday photosynthetically active radiation (PAR) values of $2500 \mu \mathrm{E}$ $\mathrm{m}^{-2} \mathrm{~s}^{-1}$ at the sea surface, and the $50 \%$ light level at $15 \mathrm{~m}$, the depth of population maxima, the bulk of the Trichodesmium population should be photosynthesizing optimally. The total carbon fixed at $1410 \mu \mathrm{E} \mathrm{m}^{-2} \mathrm{~s}^{-1}$ in $10 \mathrm{~h}$ of daylight for a colony which contained $50 \mathrm{ng}$ chl a (Carpenter 1983) was $5.9 \mu \mathrm{g} \mathrm{C}$ for $T$. erythraeum and $6.8 \mu \mathrm{g} \mathrm{C}$ for $T$. thiebautii. The rate of respiration of colonies is lower at night than during the day ( $\mathrm{T}$. Roenneberg \& E. J. Carpenter unpubl.), and data collected between sundown and sunrise on the same cruise gave a mean ( 21 measurements) respiration rate of $4.1 \mu \mathrm{g} \mathrm{C} \mu \mathrm{g} \mathrm{chl} a^{-1} \mathrm{~h}^{-1}$. The $14 \mathrm{~h}$ of respiration per night yielded a total night time respiration of $2.9 \mu \mathrm{g} \mathrm{C}$ colony $^{-1}$. Applying this rate to both species, results in a total net carbon fixation rate of 3.9 and $3.0 \mu \mathrm{g} \mathrm{C}$ colony $^{-1} \mathrm{~d}^{-1}$ for $T$. thiebautii and $T$. erythraeum, respectively. Particulate carbon content of these colonies averaged $11.2 \mu \mathrm{g} \mathrm{C}$ for $T$. erythraeum and $11.9 \mu \mathrm{g} \mathrm{C}$ for T. thiebautii (Table 4). Using these mean particulate carbon values, the carbon doubling times at $1410 \mu \mathrm{E}$ $\mathrm{m}^{-2} \mathrm{~s}^{-1}$ would be $3.0(\mathrm{SD}=1.56) \mathrm{d}$ for $T$. thiebautii and $3.8(\mathrm{SD}=1.82) \mathrm{d}$ for $T$. erythraeum. These values should be typical of division rates in the euphotic zone at light intensities above $I_{k}$ (Table 3 ), and are considerably faster than that of $18 \mathrm{~d}$ determined by Li et al. (1980) in the southeastern Caribbean Sed, but similar to doubling times based on nitrogen recently calculated by Carpenter et al. (1987). Furthermore, these carbon doubling times are about 3 times faster than the average of 10 d used by Carpenter \& Romans (1991) in estimating the importance of Trichodesmium in the tropical North Atlantic Ocean. Considering that the mean of 3.0 and $3.8 \mathrm{~d}$ occurred over a $1300 \mathrm{n}$ mile transect, and is about 3 times more rapid than the doubling time used by Carpenter \& Romans (1991), it is probable that Trichodesmium may be more important in oceanic $\mathrm{C}$ and $\mathrm{N}$ cycling than calculated.

Both species have relatively high concentrations of the accessory pigment phycoerythrin (PE). The PE in Trichodesmium absorbs over a relatively broad wavelength, having 3 peaks (Fujita \& Shimura 1975), and is efficient in the transfer of light energy to chl $a$. Because of this, the calculation of photosynthetic rates based on chl a can be misleading, giving the appearance that Trichodesmium spp. are more active in regard to photosynthetic capacity than phytoplankton which have no PE.

Paradoxically, the observed 4 -fold higher concentrations of (PE) in Trichodesmium erythraeum, as compared with $T$. thiebautii, would appear to be characteristic of a deep-water species accustomed to living at low light intensities rather than that of a more highly buoyant species. The reason for the higher PE content in $T$. erythraeum is thus far unknown, but it may be related to the fact that the nitrogen storage reserve, cyanophycin, has been observed in $T$. thiebautii but not in $T$. erythraeum (Siddiqui et al. 1992c). Phycoerythrin may function as a nitrogen storage reserve in $T$. erythraeum.

Differences in content of other pigments in these 2 species were not immediately obvious. Previous research by Hogetsu \& Watanabe (1975) has indicated the presence of $\beta$-carotene, echinenone and myxoxanthophyll in addition to PE and chl a (Hogetsu \& Watanabe 1975). They also found a very high degree of variability in pigment content from one location to another. During 3 research cruises over 3 yr between 1971 and 1973 , the $\beta$-carotene content, as a percentage of chl $a$ (weight), ranged from 1 to $23 \%$ and averaged $8.8 \%$. The mean echinenone content was less than $0.1 \%$ of the chl $a$, while myxoxanthophyll averaged $1.7 \%$, and reached as much as $11 \%$ of the chl $a$.

The reasons for the dominance of Trichodesmium thiebautil or $T$. erythraeum in some locations are not immediately clear, since photosynthetic characteristics of the 2 species were very similar, and growth rates were not greatly different. Acetylene reduction rates of T. thiebautii averaged 1.6 times greater than $T$. erythraeum on a per colony basis, suggesting better capacity for $\mathrm{N}_{2}$ fixation. One major factor regulating abundance of these species might be the presence of a neurotoxin (Hawser et al, 1991) which has been observed in $T$. thiebautii, but not in $T$. erythraeum, and this may allow more grazing to occur on the latter spe- 
cies. There are further possible differences in ultrastructure which may affect abundance, for example, cyanophycin granules ( $\mathrm{N}$ storage), vacuole-like structures, and scroll bodies have not yet been observed in $T$. erythraeum, whereas they have in $T$. thiebautii (Siddiqui et al. 1992c). The absence of these ultrastructures may affect the survival ability of $T$. erythraeum.

In conclusion, 2 planktonic cyanobacteria, Trichodesmium thiebautii and T. erythraeum, are similar as regards particulate $\mathrm{C}$ and $\mathrm{N}$ content, and photosynthetic rates. They differ in that $T$. erythraeum has a higher phycoerythrin content, but a lower rate of nitrogenase activity at saturating light intensities. Previous studies have shown differences in some cell inclusions, as well as in buoyancy and gas vesicle collapse pressure. Both appear to be well adapted to photosynthesis at high light intensities in near surface waters, and our measurements indicate very high photosynthetic capacity and the potential for high growth rates at light intensities typically found at their depth maxima. Particulate carbon turnover times indicate that, at the light intensities found at its depth maxima (15 m), these species are dividing at a relatively rapid and consistent rate over a large region of the southwestern North Atlantic Ocean.

Acknowledgements. We thank Barbara Dorf, Molly Reeder and Veronica Miller tor technical help, and B. Marley, P. Tosh and J. Buffet for inspiration. This research was funded by NSF grant OCE 9015606 to E.J.C., and NSF OCE 89023063 to R.D., NSF OCE 9012199 to D.G.C. and by the Bank of Sweden Tercentenery Foundation and the Teyggers Foundation grant to B.B., the Government of Pakistan graduate student scholarship to P.J.A.S., and grant Ro 656/2 from the Deutsche Forschungsgemeinschaft to T.R. This is Contribution 877 from the Marine Sciences Research Center

\section{LITERATURE CITED}

Anagnostides, K., Komarek, J. (1988). Modern approach to the classification system of cyanophytes, 3 - Oscillatoriales. Arch. Hydrobiol. Suppl. 80(1-4): 327-472

Aruga, Y., Ichimura, S., Fujita, Y. Shimura, S., Yamaguchi, Y. (1975). Characteristics of photosynthesis of marine planktonic blue-green algae, Trichodesmium. In: Marumo, R. (ed.) Studies on the community of marine pelagic bluegreen algae 1972-74, Ocean Research Inst., Tokyo, p. $48-55$

Bryceson, I., Fay, P. (1981). Nitrogen fixation in Oscillatoria (Trichodesmium) erythraea in relation to bundle formation and trichome differentiation. Mar. Biol. 61: 159-166

Capone, D. G., O'Neil, J. M., Zehr, J., Carpenter, E. J. (1990). Basis for diel variation in nitrogenase activity in the marine planktonic cyanobacterium Trichodesmium thiebautii. Appl. environ. Microbiol. 56: 3532-3536

Carpenter, E. J. (1983). Physiology and ecology of marine planktonic Oscillatoria (Trichodesmium). Mar. Biol. Lett. 4: $69-85$

Carpenter, E. J., Price, C. C. (1977). Nitrogen fixation, distribution and production of Oscillatoria (Trichodesmium) spp. in the western Sargasso and Caribbean Seas. Limnol. Oceanogr. 22: 60-72

Carpenter, E. J., Romans, K. (1991). Major role of the cyanobacterium Trichodesmium in nutrient cycling in the North Atlantic Ocean. Science 254: 1356-1358

Carpenter, E. J., Scranton, M. I., Novelli, P. C., Michaels, A. (1987). Validity of $\mathrm{N}_{2}$ fixation rate measurements in marine Oscillatoria (Trichodesmium). Limnol. Oceanogr. 9: 1047-1056

Desikachary, T V. (1959). Cyanophyta. Indian Council of Agricultural Research, New Delhi

Devassy, V. P., Bhattathiri, P. M. A., Quasim, S. Z. (1978). Trichodesmium phenomenon. Indian J. mar. Sci. 7: 168-186

Fujita, Y., Shimura, S. (1975). Photosynthesis and photosynthetic pigments of Trichodesmium. In: Marumo, R (ed.) Studies on the community of marine blue-green algae. Ocean Research Inst., Tokyo, p. 65-71

Gantt, E., Ohki, K., Fujita, Y (1984). Trichodesmium thiebautii; structure of a nitrogen-fixing marine blue-green alga (Cyanophyta). Protoplasma 119: 188-198

Hawser, S. P., Codd, G. A. (1992). The toxicity of Trichodesmium blooms from Caribbean waters. In: Carpenter, E. J., Capone, D. G., Rueter, J. G. (eds.) Marine pelagic cyanobacteria: Trichodesmium and other diazotrophs. Kluwer Academic Publishers, Dordrecht, p. 319-329

Hawser, S. P., Codd, G. A., Carpenter, E. J., Capone, D. G. (1991). A neurotoxic factor associated with the bloomforming cyanobacterium Trichodesmium. Toxicon 29: $277-278$

Hogetsu, K., Watanabe, M. F. (1975). Photosynthetic pigments in Trichodesmium: identification and determination of carotenoids. In: Marumo, R. (ed.) Studies on the community of marine pelagic blue-green algae. Ocean Research Inst., Tokyo, p. 36-40

Holm-Hansen, O., Reimann, B. (1978). Chlorophyll a determination: improvements in methodology. Oikos 30: 438-447

Kana, T. M. (1992). Oxygen cycling in cyanobacteria with special reference to oxygen protection in Trichodesmium spp. In: Carpenter, E. J., Capone, D. G., Rueter, J. G. (eds.) Marine pelagic cyanobacteria: Trichodesmium and other diazotrophs. Kluwer Academic Publishers, Dordrecht, p. $29-41$

Lewis, M. R., Ulloa, O., Platt, T. (1988). Photosynthetic action, absorption, and quantum yield spectra for a natural population of Oscillatoria in the North Atlantic. Limnol. Oceanogr. 33: 92-98

Li, W. K. W., Glover, H. E., Morris, I. (1980). Physiology of carbon photoassimilation by Oscillatoria thiebautii in the Caribbean Sea. Limnol. Oceanogr. 25: 447-458

Marumo, R., Nagasawa, S. (1976) Seasonal variation of the standing crop of a pelagic blue-green alga, Trichodesmium, in the Kuroshio water. Bull. Plankton Soc. Japan 23: $19-25$

McCarthy, J. J., Carpenter, E. J. (1979). Oscillatoria (Trichodesmium) thiebautii (Cyanophyta) in the central North Atlantic Ocean. J. Phycol. 15: 75-82

Moreth, C. M., Yentsch, C. S. (1970). A sensitive method for the determination of open ocean phytoplankton phycoerythrin pigments by fluorescence. Limnol. Oceanogr. 15: $313-317$

Qasim, S. Z. (1972). Some observations on Trichodesmium blooms. In: Desikachary, T. V. (ed.) Proceedings of the symposium on taxonomy biology of blue-green algae. Bangalore Press, Bangalore, p. 433-438

Siddiqui, P. J. A., Bergman, B., Bjorkman, P. O., Carpenter, E. J. (1992a). Ultrastructural and chemical assessment of poly- $\beta$-hydroxybutyric acid in the marine cyanobacterium 
Trichodesmium thiebautii. FEMS Microbiol. Lett. 94: $143-148$

Siddiqui, P. J. A., Bergman, B. Carpenter, E. J. (1992b). Filamentous cyanobacterial associates of the marine planktonic cyanobacterium Trichodesmium. Phycologia 31: 326-337

Siddiqui, P. J. A., Carpenter, E. J., Bergman, B. (1992c). Trichodesmium: ultrastructure and protein localization. In: Carpenter, E. J., Capone, D. G., Rueter, J. G. (eds.) Marine pelagic cyanobacteria: Trichodesmium and other diazotrophs. Kluwer Academic Publ, Dordrecht, p. 9-28

Smith, E. L. (1936). Photosynthesis in relation to light and carbon dioxide. Proc. Natl Acad. Sci. U.S.A. 22: 504-511

This article was presented by J. Fuhrmann, Los Angeles, California, USA
Sournia, A. (1968). La Cyanophycée Oscillatoria (Trichodesmium) dans le plancton marin: taxonomie, et observations dans le Canal de Mozambique. Nova Hedwigia 15 $1-12$

Villareal, T. A., Carpenter, E. J. (1990). Diel buoyancy regulation in the marine diazotrophic cyanobacterium Trichodesmium thiebautii Limnol. Oceanogr. 35: 1832-1837

Walsby, A. E. (1978). The properties and buoyancy-providing role of gas vacuoles in Trichodesmium, Ehrenberg. $\mathrm{Br}$. Phycol. J. 13: 103-116

Wyman, M. (1992). An in vivo method for the estimation of phycoerythrin concentrations in marine cyanobacteria (Synechococcus spp.). Limnol Oceanogr. 37: 1300-1306

Manuscript first received: July 3, 1992

Revised version accepted: February 9, 1993 